\title{
Recruitment and ontogenetic habitat shifts of the yellow snapper (Lutjanus argentiventris) in the Gulf of California
}

\author{
Octavio Aburto-Oropeza • Isaí Dominguez-Guerrero • \\ José Cota-Nieto · Tomás Plomozo-Lugo
}

Received: 26 November 2008/ Accepted: 23 July 2009/Published online: 8 August 2009

(C) The Author(s) 2009. This article is published with open access at Springerlink.com

\begin{abstract}
We examined recruitment and ontogenetic habitat shifts of the yellow snapper Lutjanus argentiventris in the Gulf of California, by conducting surveys and collections in multiple mangrove sites and major marine coastal habitats from 1998 to 2007. Over 1,167 juvenile individuals were collected and 516 otoliths were aged to describe the temporal pattern of the settlement. L. argentiventris recruits in mangroves, where juveniles remain until they are approximately $100 \mathrm{~mm}$ in length or 300days-old. Back-calculated settlement dates and underwater surveys indicated a major recruitment peak during September and October, around 8 days before and after the full moon. The majority of mangrove sites in the Gulf of California had a similar L. argentiventris average size at the beginning of the settlement season for the cohort of 2003; although there were significant differences in individual sizes at the end of the nursery stage. When subadults leave mangroves, they live in shallow rocky reefs and later become abundant in deeper rocky reefs. The density of migratory individuals $(10-20 \mathrm{~cm} \mathrm{SL})$ decreased
\end{abstract}

Communicated by X. Irigoien.

Electronic supplementary material The online version of this article (doi:10.1007/s00227-009-1271-5) contains supplementary material, which is available to authorized users.

O. Aburto-Oropeza $(\bowtie) \cdot$ I. Dominguez-Guerrero ·

J. Cota-Nieto · T. Plomozo-Lugo

Departamento de Biología Marina, Universidad Autónoma de

Baja California Sur, Carretera al sur km 5.5,

La Paz 23081, Mexico

e-mail: maburto@ucsd.edu

O. Aburto-Oropeza

Center for Marine Biodiversity and Conservation,

Scripps Institution of Oceanography, 9500 Gilman Drive,

La Jolla, CA 92093-0202, USA exponentially as the distance between a reef and a nearby mangrove site increased. This finding has important implications for local fishery regulations and coastal management plans.

\section{Introduction}

Various commercial reef fish species, such as groupers, snappers, and jacks have life cycles that include more than one habitat during their lives (see review by Gillanders et al. 2003). From a biological perspective, it is thought that different habitats confer different survival advantages for different life stages, and therefore that ontogenetic habitat shifts have evolved to maximize individual survival probability (Morris 2006). However, from a fisheries management perspective, species with complex life cycles are more vulnerable to anthropogenic impacts, since habitat destruction and fragmentation increases the probabilities of overexploiting their populations (Coleman and Williams 2002).

Ontogenetic habitat shifts is a common strategy between reef fish species the larvae of which settle in other benthic habitats that serve as early juvenile nurseries. Coastal systems, such as sea grasses, kelp forests, mangroves, or estuaries represent important nursery habitats before individuals migrate to adult habitats (Koenig and Coleman 1998; Nagelkerken et al. 2000; Nelson 2001; Cocheret de la Moriniere et al. 2002). Variability in juvenile populations in these nursery habitats is reflected years later in the size structure of the adult populations (Russ et al. 1996; Attrill and Power 2002; Aburto-Oropeza et al. 2007), and affects fishery stocks (Gillanders et al. 2003; Fodrie and Levin 2008). For that reason, information on juvenile ecology, when incorporated to fishery stock assessments, 
can provide better forecasting results than assessments based exclusively on traditional fisheries catch-at-age data (Coleman et al. 2000). This type of information may also prove useful in establishing legislative frameworks for fisheries management.

Several species of snappers are dependent on mangrove forests during their first year of age (Nagelkerken et al. 2000; Cocheret de la Moriniere et al. 2002; GonzálezAcosta et al. 2004). These habitats have been categorized as nursery sites, because they have above-average densities of juvenile fish compared to other habitats (Beck et al. 2001). At least six species of snappers use mangrove forests as their major nursery habitat in the Gulf of California (Thomson et al. 2000): Mexican barred snapper Hoplopagrus guentherii, mullet snapper Lutjanus aratus, yellow snapper L. argentiventris, colorado snapper L. colorado, spotted rose snapper $L$. guttatus, and $\operatorname{dog}$ snapper $L$. novemfasciatus. Adults of these species contribute 300 metric tons of fisheries landings per year in the region (RamírezRodríguez and Hernández-Herrera 2000), approximately $5 \%$ of all commercial reef fish landings.

The yellow snapper, $L$. argentiventris is one of the most important commercial species in the southern gulf, and generates more than 3 metric tons of landings per fishing cooperative during spring and summer. The species can reach sizes of up to $1 \mathrm{~m}$ in length, a weight of $10 \mathrm{~kg}$, reach maturity after 3 years, and can live up to 19 years (Martinez-Andrade 2003). Fishermen report aggregations of gravid individuals near May and June, and spawning aggregations have been observed in several islands in the southern Gulf of California (Sala et al. 2003).

Baja California is the northern limit of mangrove forests in the Eastern Pacific. In this region, mangroves grow under suboptimal conditions and individual plants consist of shrubs or small trees, which form isolated mangrove patches with a relatively narrow band of adjacent desertfringe vegetation (Whitmore et al. 2006). Despite their limited extent, these coastal forests represent an important source of food production and income for local communities (Aburto-Oropeza et al. 2008). Since these scarce and isolated ecosystems are thought to represent the most important sources of replenishment of L argentiventris populations in marine habitats, we aim to demonstrate the relationship between the distribution of mangrove sites and L. argentiventris abundance.

As described by Gillanders et al. (2003), a variety of methods have been used to determine movement from juvenile to adult habitats. Direct evidence of movement can only be measured by observing individually recognized or tagged organisms shifting from one place to another. However, indirect information on the movement of individuals can be obtained by differences in distribution, abundance, and size structure, and by differences in physical stages of maturity. To use these indirect methods, there is a clear need to obtain information on abundance and size distribution of organisms from a range of juvenile and adult habitats, while sampling all types of habitat at several locations and multiple times. In the present study, we examined the spatial and temporal recruitment patterns of $L$. argentiventris and its ontogenetic habitat shifts. In particular, we analyzed the growth rate and residence time of fish in mangroves and other major marine habitats.

\section{Materials and methods}

Study area

This study was conducted in multiple mangrove sites and marine habitats in the Gulf of California, between $22^{\circ} 00^{\prime} \mathrm{N}$ and $29^{\circ} 30^{\prime} \mathrm{N}$, on both Baja California and Mexico's mainland coasts (Fig. 1a). In Baja California, mangrove forests are distributed from the Cape region in the southern tip to small islands in Bahía de Los Angeles in the north. In Baja California mangroves are distributed in isolated mangrove patches, most notably in the southern region (Contreras-Espinosa and Warner 2004; Whitmore et al. 2006). There are three main species: red mangrove (Rhizophora mangle), black mangrove (Avicennia germinans), and white mangrove (Laguncularia racemosa). Halophytic or salt scrub vegetation, typically associated with mangroves on the landward side (Whitmore et al. 2006) includes perennial saltgrasses (e.g., Jouvea pilosa, Monanthochloe littoralis, and Sporobolus virginicus), perennial halophytic shrubs (e.g., Allenrolfea occidentalis, Maytenus phyllanthoides, and Salicornia subterminalis), and other halophytes (e.g., Atriplex barclayana, Batis maritima, Heliotropium curassavicum, and Salicornia bigelovii).

On the mainland, mangrove forests are distributed from Tiburon Island in Sonora, south to Sinaloa and Nayarit, where coastal lagoons have extensive mangrove forests. Mangroves in Sonora include some of the same halophyte species (e.g., Salicornia) seen in the peninsula, but these species can be submerged in water and, together with sea grasses (Zostera marina and Ruppia maritima), they represent another benthic habitat within the mangrove forests.

We collected juvenile Lutjanus argentiventris from 12 mangrove sites and conducted 1,467 dives between 1998 and 2007 , from $<1$ to $50-\mathrm{m}$ depth, across the following major marine habitats (Supplementary material S1):

(1) Habitats adjacent to mangrove sites $(<3 \mathrm{~m})$. These include rocky boulders at the mouth of coves and bays, and shallow boulder beds covered seasonally by Sargassum spp. along the rocky shores; 
Fig. 1 Map of Gulf of California showing: a the major marine habitat types surveyed off the coast of the Baja California peninsula and Mexico's mainland, including the location of the 12 mangrove sampling sites (see,

Supplementary material S1); and $\mathbf{b}$ the benthic habitats of Balandra mangrove, where the principal snapper collections and juvenile surveys were carried out. Codes for sites in the peninsula: $S J$ San Jose, $P E$ Puerto Escondido, $S B$ San Basilio, RE Requeson, $S M$ San Marcos, and SL San Lucas. Codes for sites in the mainland: $B P$ Barra de Piaxtla, $B O$ Bojorquez, $P Y$ Punta Yavaros, ES El Soldado, and $T A$ Tajce

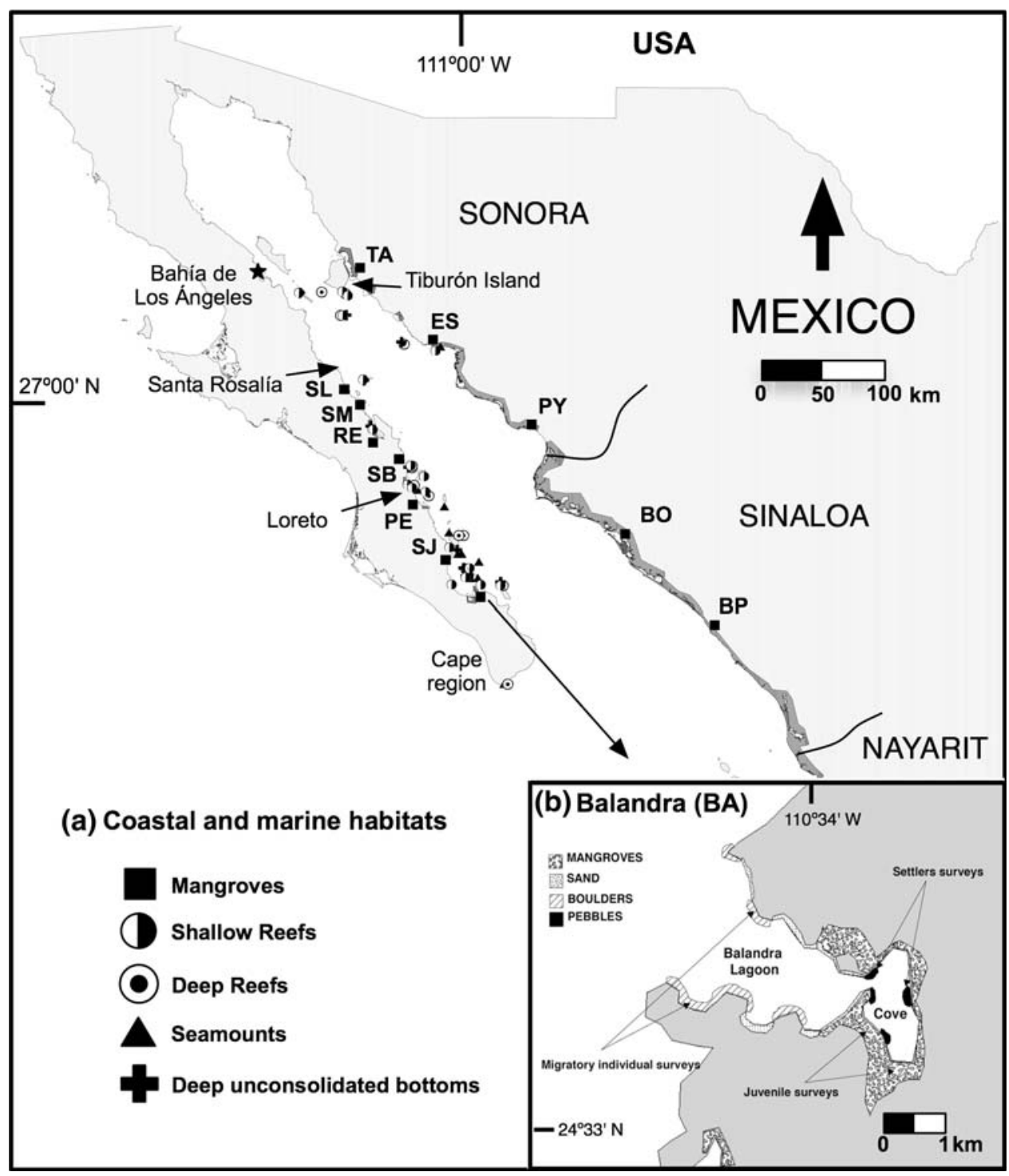

(2) Rocky reefs, shallow (5 m) and deep (20 m). These include boulder beds and vertical walls in coastal and island areas. Rocky reefs are colonized by a high diversity of benthic suspension feeders, such as gorgonians, hydroids, cup corals, sponges, tunicates, and bryozoans;

(3) Seamounts. These are deeper (30-40 m) offshore rocky reefs subjected to strong currents. The sessile fauna colonizing seamounts is similar to that of vertical walls, with abundant suspension feeders;

(4) Deep unconsolidated bottoms $(>15 \mathrm{~m})$. These include rhodolith beds and black coral beds. Rhodoliths are free-living calcareous algae (Corallinaceae) that grow up to $20 \mathrm{~cm}$ in diameter, form fields of variable cover over soft bottoms, and can include sparse free-living corals. Fields of black coral, Antipathes galapaguensis, occupied horizontal, as well as gently sloped rocky and dead shell substrata below $25 \mathrm{~m}$.
As part of a larger project (Aburto-Oropeza 2009), we collected L. argentiventris individuals of all sizes in the major marine habitats mentioned above, and surveyed 51 mangrove sites in the southern Gulf of California since 2005 in order to: (1) establish the size-maturity structure of L. argentiventris populations; (2) estimate and compare life history variables for L. argentiventris population dynamics (Supplementary material S2); and (3) establish the size distribution of L. argentiventris that can be observed inside mangroves seasonally. Through these research efforts we have established the following broad size-ontogenetic categories (TL, total length) based on L. argentiventris maturity: settlers $<3 \mathrm{~cm}$; post-settlers inside mangrove roots between 4 and $10 \mathrm{~cm}$; immature migratory individuals between 10 and $20 \mathrm{~cm}$; and (mature) adult individuals $>25 \mathrm{~cm}$. 
Underwater surveys of juvenile and adult individuals

Estimates of Lutjanus argentiventris abundance were carried out by free diving inside mangrove sites and by SCUBA diving for the other habitats. We used standard underwater visual belt transect survey methods (HarmelinVivien et al. 1985) in all the habitats sampled. The authors are experienced at visually surveying fish assemblages and also at estimating fish lengths accurately (Aburto-Oropeza and Balart 2001; Sala et al. 2002); the ability of the authors to estimate lengths was validated using artificial fish figurines as part of their training process. Total length of juveniles was estimated to the nearest $1 \mathrm{~cm}$ for individuals $<10 \mathrm{~cm}$ in length, and every $5 \mathrm{~cm}$ for individuals larger than $10 \mathrm{~cm}$. Based on previous observations regarding habitat use of settlers, all mangrove sites were divided into two benthic habitats: pebble beds (shallow areas with gentle slopes, covered by pebbles and small boulders $\left[\approx 1,000 \mathrm{~cm}^{3}\right]$ over sandy bottoms), and mangrove roots. To estimate the abundance of juvenile snappers, six replicates, $50 \times 1 \mathrm{~m}$, transects were surveyed in pebble beds covering an area of $50 \mathrm{~m}^{2}$. In mangrove roots we surveyed snappers by swimming parallel to the mangrove fringe and counting fish $1 \mathrm{~m}$ inside and outside the prop roots (six replicates, $50 \times 2 \mathrm{~m}$, transects; $100 \mathrm{~m}^{2}$ ). Six replicates, $50 \times 5 \mathrm{~m}$, transects were surveyed at the habitats adjacent to mangroves, rocky reefs, seamounts, and rhodolith beds. For black coral beds transects were of $30 \times 2 \mathrm{~m}$. Divers swam each transect at constant speed, about 15 min per transect, counting and estimating the size of all individuals within $2.5 \mathrm{~m}$ to either side of the center line for the adjacent habitats, shallow and deep rocky reefs, seamounts and rhodoliths ( $250 \mathrm{~m}^{2}$ transect area); and $1 \mathrm{~m}$ to either side for black coral beds $\left(60 \mathrm{~m}^{2}\right)$.

To estimate the number of $L$. argentiventris settlers that arrived at a nursery area, we monitored a cove with a mangrove patch of 22 ha (Balandra, Fig. 1b) from February 2005 through May 2006, every four days on an average ( $\pm 3.2 \mathrm{SD}$ ). Underwater surveys were carried out as described above in areas covered by pebbles and in mangrove roots. Although we counted $L$. argentiventris of all sizes, we considered only those with a total length $<3 \mathrm{~cm}$ (younger than 50 days) as the individuals that settled during the same-year-reproduction event.

Juvenile collections and lab analyses

The information generated using otolith daily increments correspond primarily to Lutjanus argentiventris juveniles collected in 2002 in Balandra. We collected at least 20 individuals of different sizes every 15 days from February 2002 through March 2003 using push nets (small trawl nets attached to a frame and hand-operated by two people) and small spear guns. We performed between five and ten $20-\mathrm{m}$ tows parallel to the mangrove roots. If these tows were not enough to collect more than 20 individuals, we used the spear guns and worked for a period of $4 \mathrm{~h}$ collecting as many fish as possible. We took additional samples from the same site in June and October of 2003, 2004, and 2005.

To compare size distributions and daily growth of juveniles at a larger spatial scale, we sampled 11 additional mangrove sites along Baja California and the mainland (Fig. 1a). These sampling expeditions were carried out during the recruitment peak and the end of the nursery stage (see "Results") of the 2003 cohort, in October 2003 and June 2004, respectively.

After collection, specimens were preserved in $95 \%$ ethyl alcohol and transported to the laboratory at Universidad Autónoma de Baja California Sur in La Paz for analyses. Juveniles were measured (total length, TL, and standard length, SL) to the nearest $0.1 \mathrm{~mm}$, and weighed to the nearest $0.1 \mathrm{~g}$. The sagittae and lapilli were extracted using a dissecting microscope, glass knives, and ceramic forceps. One lapillus from each fish was chosen randomly, prepared and polished following the methods described by Secor (1992). The other otoliths were stored dry in vials.

Lapilli were prepared for age determination by polishing both lateral surfaces on glass plates covered with CristalBond $^{\circledR}$. We used different polishing cloths, including 12, 9, 3 , and $0.3 \mu \mathrm{m}$. Polished otoliths were mounted on microscope slides using immersion oil. Increments were counted from the nucleus outward to the edge of the otolith, or to the settlement mark that was associated with the transition from planktonic stage to benthic habitat (Wilson and McCormick 1999). The settlement mark was interpreted where the pattern in the increment widths changed markedly (Wellington and Victor 1992).

Otolith microstructure was examined using a light microscope $(100 \times$ to $800 \times$ magnification $)$ and by counting increments. Readings were done twice by the same reader. Counts that differed by not greater than $5 \%$ were averaged; increment counts that differed by more than $5 \%$ were counted a third time, and if the third count differed by more than this percentage, the otolith was rejected (Allman and Grimes 2002). We used the validation of the periodicity of increment formation in lapilli described by Zapata and Herron (2002), which showed that juvenile L. argentiventris produce one ring per day.

\section{Data analyses}

A settlement date for each individual was calculated by subtracting the number of post-settlement increments (growth rings between the settlement mark and the edge of the otolith) from the date of capture. Settlement date was converted to the lunar calendar by determining the number 
of days until the nearest full moon, with values negative during waxing stages and positive during waning stages (Fig. 3). To test for lunar periodicity in the pattern of settlement for the sampled population, we compared the relative fit of two models of settlement intensity using Poisson regression. The constant model-No. of Settlers $=\alpha-$ assumes that there is no effect of lunar date on the settlement probability. A sinusoidal model-Settlers $=\alpha+$ $\{\beta \times \sin [(2 \pi \times X / 14)-(\pi / 2)]\}$, where $\alpha$ and $\beta$ are estimated parameters and $X$ is the lunar date-assumes that the probability of settlement is a function of lunar date, reaching a minimum at full and new moons. The best-fit parameters were estimated by the Nelder-Mead optimization algorithm in R software (http://www.R-project.org).

To overlap temperature data on settlement frequency distributions, we obtained sea surface temperature (SST) data from remotely sensed satellite imagery (Terra/Aqua MODIS) at NOAA Satellite and Information Service (http://www.ncdc.noaa.gov), and calculated SST for our study region using MATLAB $^{\circledR}$ software. We obtained 15 days average of the SST and plotted them with the settlement frequency distribution obtained by date back calculation and by underwater surveys (see Fig. 4). As surveys in Balandra were systematic, we only performed a regression analysis between SST and the abundance of individuals $<3 \mathrm{~cm}$ recorded in the underwater surveys.

To test for differences in growth rates of Lutjanus argentiventris within mangrove sites, we compared the relationship between SL and the post-settlement age for samples obtained in October 2003 and June 2004. The relationship was described by a linear regression and the site effect (slope coefficient) in the relationships between SL and age, was analyzed using ANCOVA. To test for differences in size structure of $L$. argentiventris between mangrove sites and collection months (October 2003 and June 2004), log-transformed data were analyzed using ANOVA. When the interaction was significant, post-hoc multiple comparisons were analyzed using Tukey HSD tests. Transformations were made to center the means and to stabilize variances. Homogeneity of variances was tested using Cochran's $C$ test.

To establish if there were significant differences between size distributions among habitats, size-class percentages for each habitat were determined and compared using Chi-Square median test. Additionally, we used GIS in conjunction with ArcView software to calculate the nearest distance between mangrove sites and study reefs, following the contour of the coastline. To describe the influence of mangrove sites on the migratory distances of L. argentiventris, we correlated the distance to the nearest mangrove site to the density of individuals between 10 and $20 \mathrm{~cm}$ size classes at each site.

\section{Results}

Juvenile age and growth

A total of 1,167 post-settlers of Lutjanus argentiventris were captured in all mangrove sites. Their sizes (SL) ranged from 16.9 to $136.2 \mathrm{~mm}$, with a mean of $55.2 \mathrm{~mm}$ $( \pm 1.7 \mathrm{SE})$. Of these, $99 \%$ were less than $100 \mathrm{~mm} \mathrm{SL}$. Young-of-the-year, L. argentiventris had typical weightstandard length relationship of the form: $W=\left(2 \times 10^{-5}\right)$ $\mathrm{SL}^{3.05},\left(r^{2}=0.98, p<0.0001\right)$.

We aged otoliths from 516 individuals. Estimated postsettlement age ranged from 11 to 368 days (Fig. 2); $98 \%$ of these individuals were less than 300-days-old. The general model of age-length relationship was $\mathrm{SL}=0.35$, Age $+4.81,\left(r^{2}=0.88, F=3603.86, p<0.0001\right)$. The instantaneous daily growth (slope coefficient) of juvenile L. argentiventris was similar among all mangrove sites $\left(0.35 \mathrm{~mm} \mathrm{day}^{-1} \pm 0.02 \quad \mathrm{SEM}\right)$, although ANCOVA revealed a significant $(p<0.0019)$ site effect in the relationships between SL and Age, driven mainly by one site (Bojorquez mangrove, $p<0.0034$ ). Settlement at this site started at smaller lengths $(18.7 \mathrm{~mm})$ than the other sites (significant site effect for intercept), however the growth rate $\left(0.42 \mathrm{~mm} \mathrm{day}^{-1}\right)$ was higher compared to the other sites (significant site effect on the slope).

\section{Settlement patterns}

The estimated age at settlement (planktonic larval duration, PLD) of fish pooled across sites, ranged from 19 to 26 days (mean $=22.9 \pm 0.05 \mathrm{SE}$ ). The longest average PLD was recorded for juveniles setting in the San Lucas mangrove (23.9 days \pm 0.19 SE) $(p<0.001)$. Individuals that settled

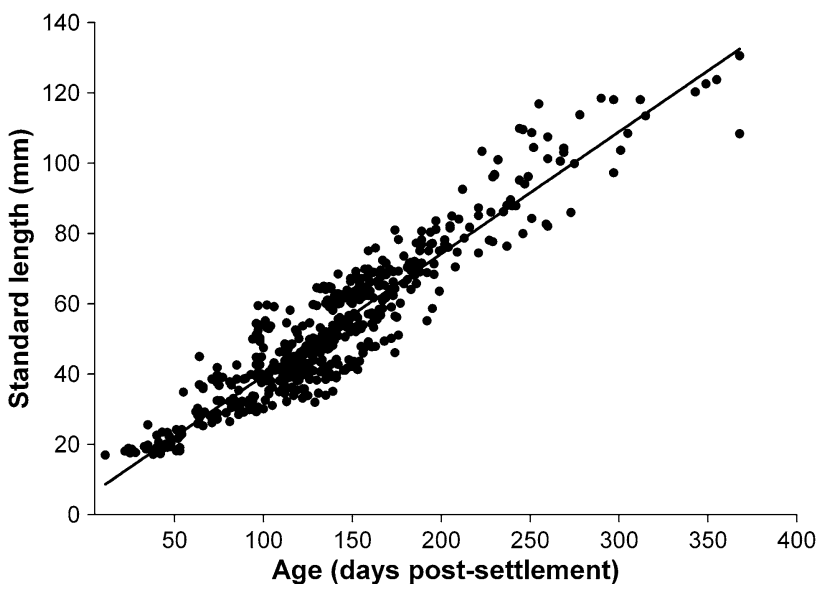

Fig. 2 Lutjanus argentiventris. Relationship between standard length and age after settlement estimated from lapilli of juveniles collected in Balandra between 2002 and 2005, and 11 additional mangrove sites during October 2003 and June 2004; $r^{2}=0.88, p<0.0001, n=516$ 
in Balandra in 2002 had a PLD significantly shorter than other samples taken in the same mangrove on subsequent years $(p<0.001)$. The settlement pattern was related to the lunar date, with a maximum frequency of settlement reached during the quarter moons (Fig. 3). The sinusoidal model fitted the settlement data much better than the constant model $(p<0.001)$, suggesting a strong lunar periodicity in the settlement patterns (Settlers $=17.2+$ $\{3.3 \times \sin [(2 \pi \times X / 14)-(\pi / 2)]\})$.

Age estimates from otolith analysis were used in conjunction with collection dates to determine the frequency distribution of settlement dates for $L$. argentiventris caught in Balandra from 2002 to 2005 (Fig. 4a). Back-calculated settlement dates ranged from early August to late January, with a major peak occurring from late September to early November in the four sampled years.

During the 2005 visual surveys in pebbles and mangrove roots from Balandra, L. argentiventris smaller than $3 \mathrm{~cm}$ first appeared during the second week of August (Fig. 4b). Most settlement occurred during September and October; however, settlers were observed through late April 2006. Settlement of L. argentiventris increased exponentially as SST increased during the year (Fig. 4b) $\left(\underline{r}^{2}=0.58\right.$, $F=19.3, p<0.001$ ).

At the beginning of the 2003 recruitment season, the majority of the 12-studied mangrove sites did not have a significant difference in $L$. argentiventris average size structure (42.7 $\mathrm{mm} \pm 0.07 \mathrm{SE}$ ) (Fig. 5). However, the largest difference in size distribution within mangrove sites were observed in Punta Yavaros, with an average size above $66 \mathrm{~mm}$, and San Basilio with an average size of $28.6 \mathrm{~mm}$ (1-way ANOVA: $F=70.506, p<0.001$ ). Significant size differences were present toward the end of the nursery stage in all mainland mangrove sites compared

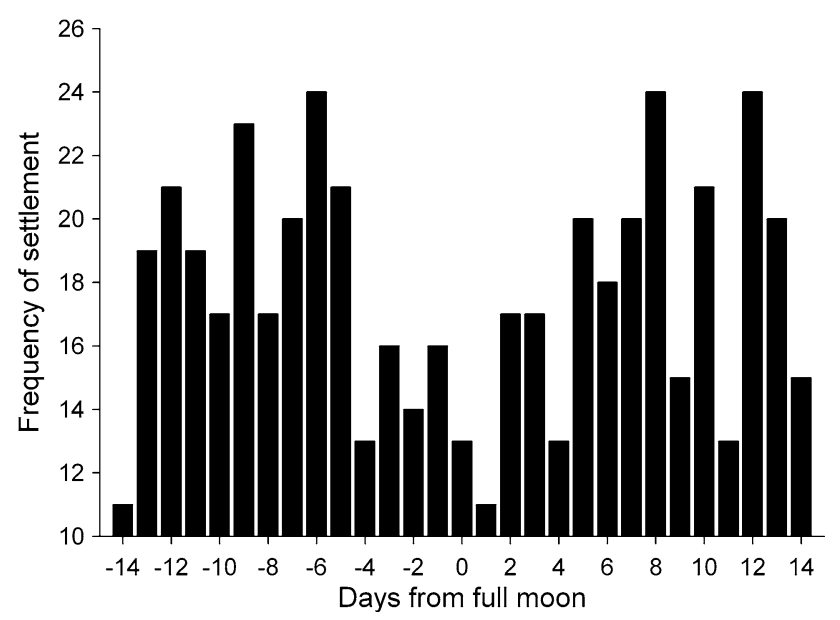

Fig. 3 Lutjanus argentiventris. Settlement frequency distribution obtained with back calculations of 516 lapilli otoliths. Zero represents full moon; -15 and 15 represent the previous and following new moons, respectively
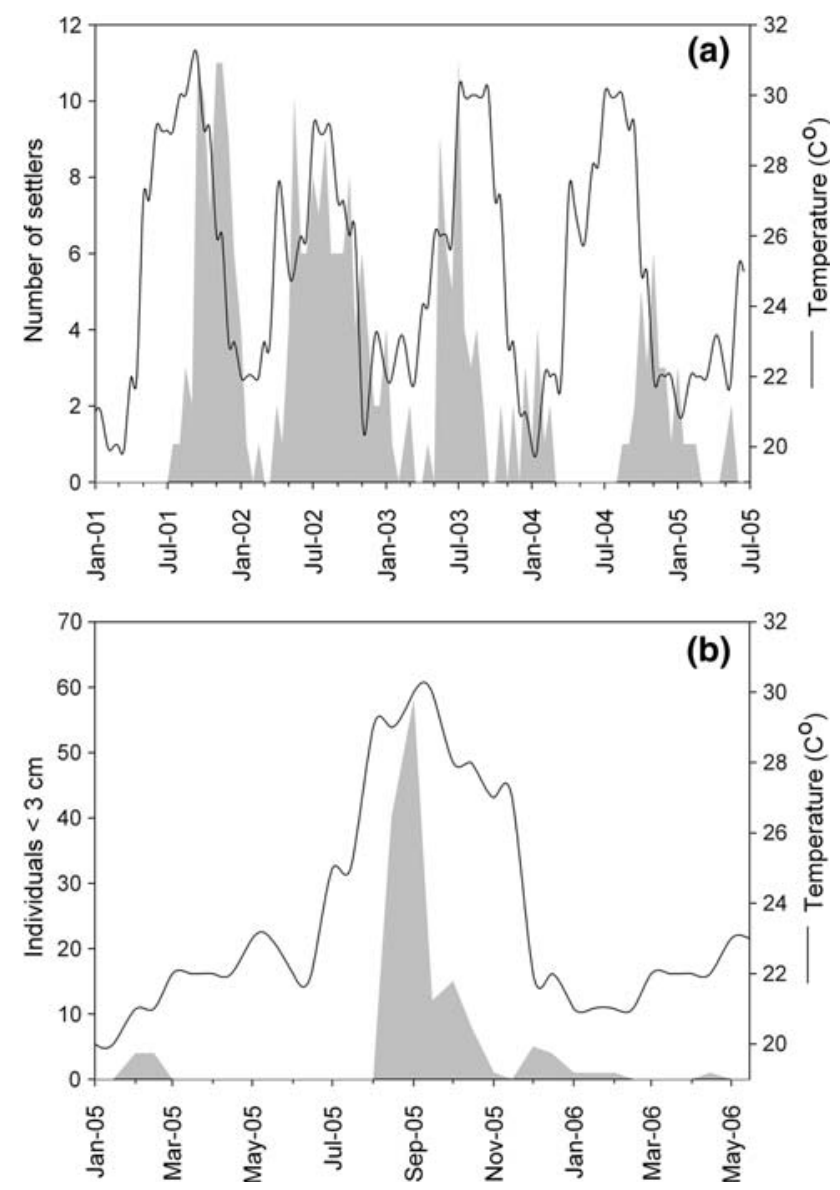

Fig. 4 Lutjanus argentiventris. Comparison of settlement time in Balandra as determined by, a back-calculation from otoliths collected from 2002 to 2005, and b survey data between February 2005 and May 2006

with the peninsula's mangrove sites (1-way ANOVA: $F=18.569, p<0.001)$. Additionally, mainland mangrove sites had average size values higher than the general mean (78.2 $\mathrm{mm} \pm 0.9 \mathrm{SE}$ ) (Fig. 5).

\section{Ontogenetic movements}

Lutjanus argentiventris showed clear ontogenetic shifts in habitat use $($ Chi-Square $=18.29, \quad d f=6, \quad p<0.01)$ (Table 1; Fig. 6). Post-settlers $(<5 \mathrm{~cm})$ were found mostly on pebble beds; they then become abundant in mangrove roots until they reached approximately $10 \mathrm{~cm}$. Migratory individuals between 10 and $20 \mathrm{~cm}$ characterized habitats adjacent to mangrove sites; adults $(25-60 \mathrm{~cm})$ have greater abundance in shallow and deep rocky reefs. Deep habitats, including seamounts and deep unconsolidated bottoms, registered the largest individuals $(>60 \mathrm{~cm})$ and were the only two habitats that did not have significant differences in average individual size $(p=0.085)$.

The density of migratory individuals decreased exponentially $\left(r^{2}=0.94, \quad F=432.38, \quad p<0.0001\right) \quad$ with 
Fig. 5 Lutjanus argentiventris. Average size of juveniles collected inside mangrove forests along the Gulf of California, during the recruitment peak (October) and the end of nursery stage (June) of cohort 2003. Codes for sites are in Fig. 1 (SM and BP were not surveyed in June 2004 because of weather conditions) Data are means; whiskers are $\pm 95 \%$ Confidence Intervals; dashed line represents overall groups mean

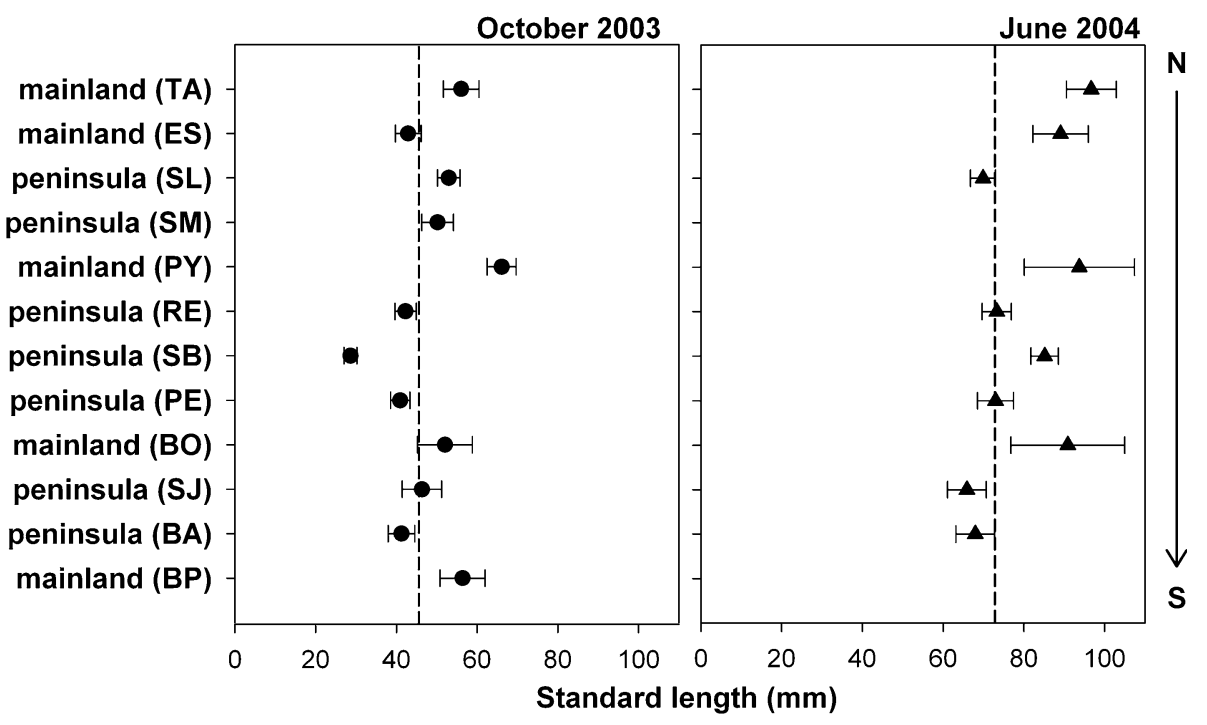

distance from the closest mangrove site (Fig. 7). In general, densities above 1 individual per $250 \mathrm{~m}^{2}$ were only found at reefs with mangrove sites closer than $10 \mathrm{~km}$.

\section{Discussion}

Ontogenetic change in habitat use is a common strategy displayed by many fish species (Macpherson 1998; Cocheret de la Moriniere et al. 2002; Mumby et al. 2004; Secor and Rooker 2005), and provides several survival advantages, such as access to food, lower predation, and less competition. This study describes the processes that take place during the Lutjanus argentiventris mangrove stage and the habitat shifts that occur once they leave the mangrove habitat, using size-frequency data as indirect evidence of ontogenetic' movement between the major marine habitats in the Gulf of California. Individuals first settle in pebbles after their pelagic larval stage, once they reach approximately $2 \mathrm{~cm}$ in length. As occurs in other species that settle during warm seasons (Macpherson 1998; Rooker et al. 2004; Faunce and Serafy 2007), L. argentiventris grows approximately $10 \mathrm{~cm}$ in total length in less than one year. Sub-adults spend some years in shallow rocky reefs where they mature, and then become abundant in deep rocky reefs where spawning aggregations take place (Sala et al. 2003).

\section{Settlement patterns}

Lutjanus argentiventris spend an average of 23 days in the water column during their pelagic stage. This is similar to other snappers that predominantly use mangroves as nursery habitats: 18 days in L. synagris, 22 days in Hoplopagrus guentherii, 23 days in L. novemfasciatus,
24 days in L. guttatus, and 25 days in L. griseus (Allman and Grimes 2002; Zapata and Herron 2002; Rooker et al. 2004). In the Gulf of California, the main spawning season for L. argentiventris is from July through September (Muhlia-Melo et al. 2003), which is consistent with the settlement season (late August-early November) observed in this study. Spawning periodicity could be an important factor that determines the settlement pattern of larvae into mangroves. Our sampling of older recruits meant that estimation of spawning frequency within a spawning season could have been influenced by variation in mortality rates of egg and larval stages, so we chose not to present this data. We found that larvae settled with semi-lunar periodicity during quarter moons (settlement frequency). The back-calculated settlement dates indicated that settlement rates during quarter moons were up to 2.5 times higher than during the full and new moons. This is particularly interesting because the majority of small mangrove forests in the Gulf of California desiccate at low tide during spring tides associated with the full and new moons (Contreras-Espinosa and Warner 2004); therefore, larvae may avoid settling in these time periods to decrease movements and decrease exposure time to predators (Biro et al. 2003), or they cannot access the settlement habitat.

\section{Growth rates}

Our results show that most mangrove sites on the peninsula and mainland had a similar size distribution at the beginning of the settlement season for the 2003 cohort, suggesting synchronized recruitment timing for the entire region. Previous studies (Allman and Grimes 2002; Rooker et al. 2004; Faunce and Serafy 2007) have demonstrated that snappers typically settle when they reach between 10 and $19 \mathrm{~mm}$ TL, and grow between 0.28 and $1 \mathrm{~mm} \mathrm{day}^{-1}$ during their first 


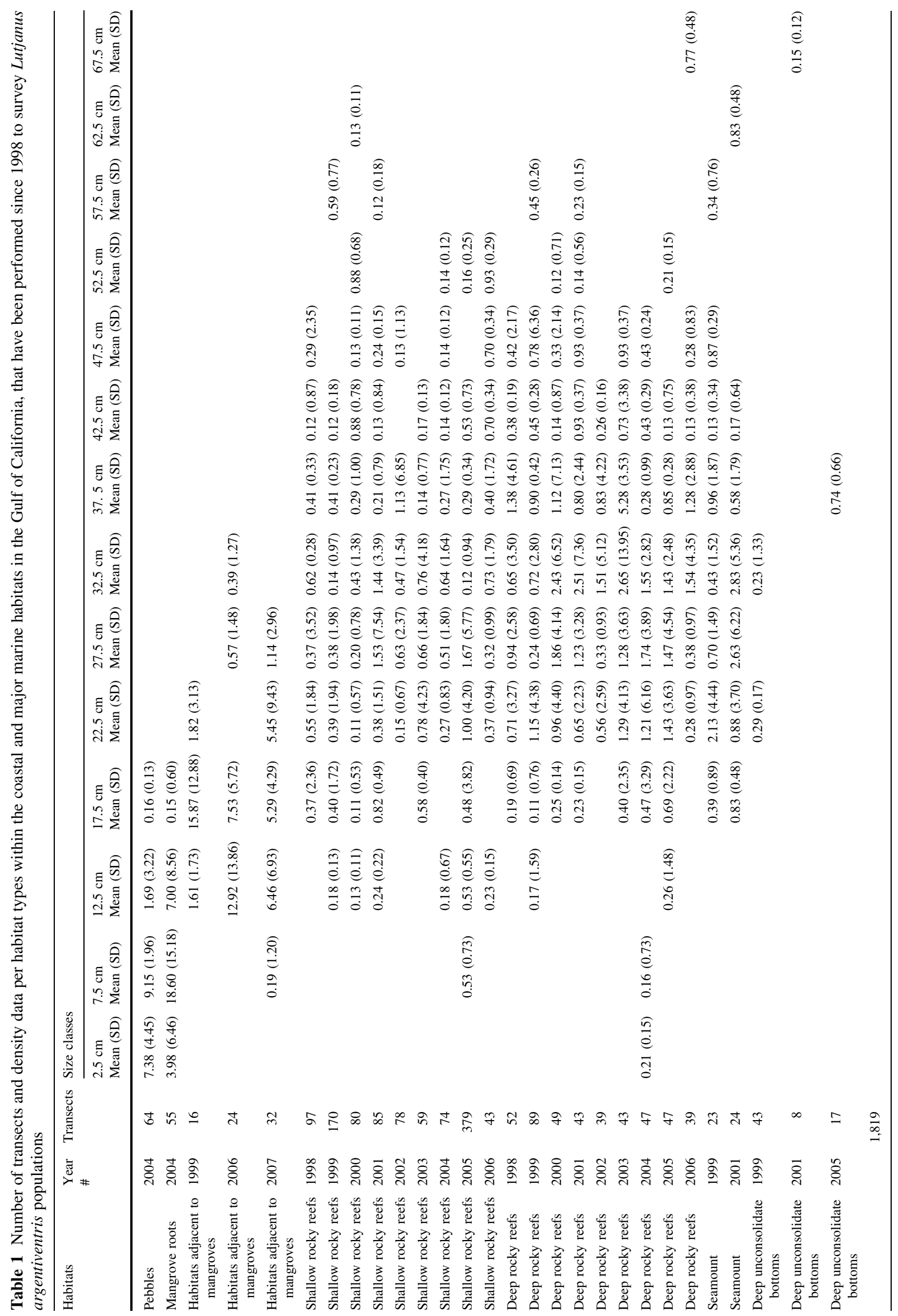




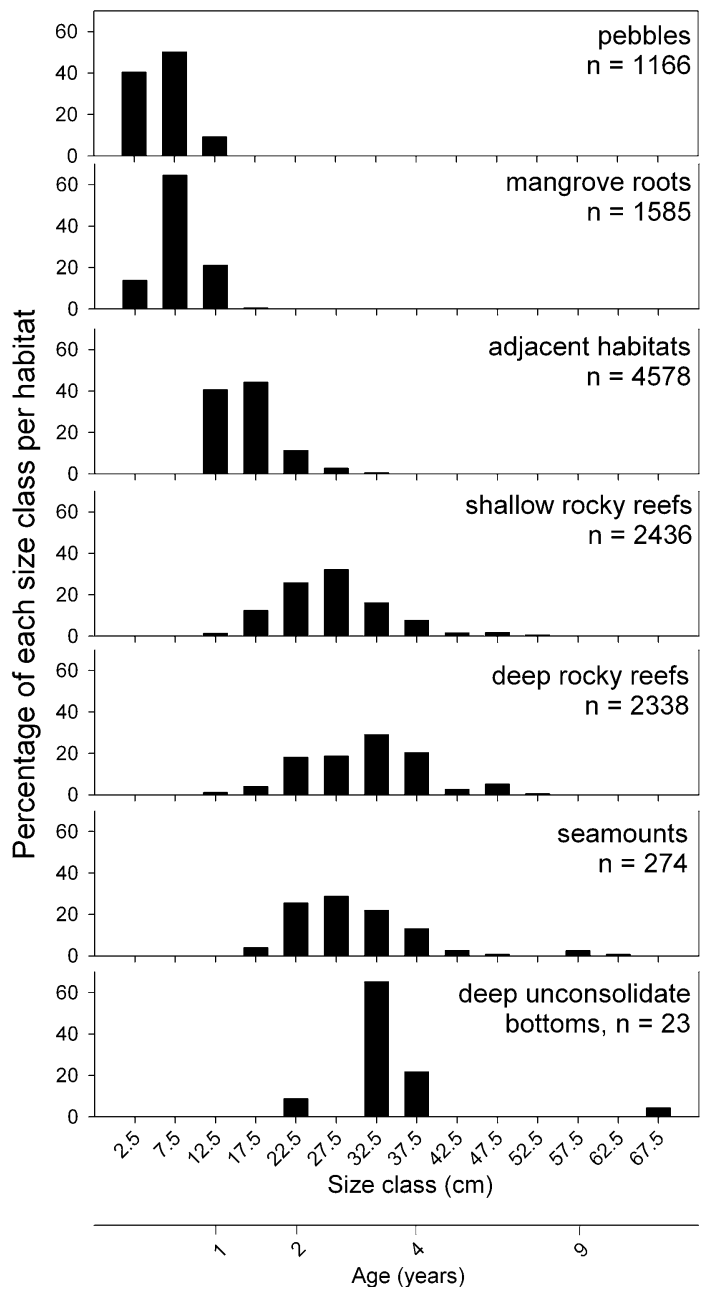

Fig. 6 Lutjanus argentiventris. Significant differences in size classes ontogenetic patterns of habitat use $(d f=6, p<0.01)$. Data are percentage of the abundance of each size-class in the underwater surveys. Histogram bars represent size-class ranges with the tick marks and scale numbers at the midpoints of the ranges. Age was calculated using age at length zero [t0], asymptotic length [Linf], and growth rate $[\mathrm{k}]$ (Supplementary material S2)

year of life. The smallest Lutjanus aregentiventris recorded in our collections had a size of $16.9 \mathrm{~mm}$ and the daily growth of these juveniles was approximately $0.35 \mathrm{~mm}_{\text {day }}{ }^{-1}$. Although we did not examine the influence of regionally varying survival rates within mangrove sites, quality of habitat (e.g., food availability, Rooker et al. 2004) and water temperature (Nixon and Jones 1997; Sumpton and Jackson 2005), are important factors that determine the growth rate of juvenile fish in nursery areas. Average temperatures inside mangrove forests in the Gulf of California during winterspring seasons are lower than those in tropical mangrove forests and may explain why the juvenile $L$. argentiventris daily growth rate is in the lower bound of snappers' growth. Growth variability was also observed among the studied mangrove sites for the 2003 L. argentiventris recruitment cohort. After the 8-month time frame between samplings

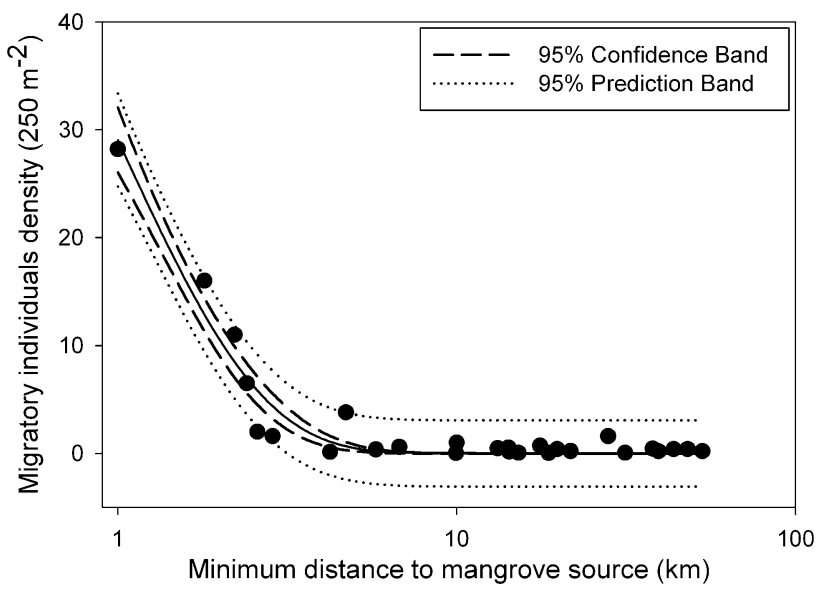

Fig. 7 Lutjanus argentiventris. Shows the relationship between nearest distance to mangrove (log-scale) and the density of individuals between 10 and $20 \mathrm{~cm}$ size classes in each reef site; $r^{2}=0.94$, $p<0.0001$. These sizes correspond to those migratory sub-adult individuals that just left mangroves

(October 2003-June 2004), all mangrove sites located on the mainland had an individual average size larger than that of individuals from mangrove sites on the peninsula. Several mangrove sites on the peninsula are small mangrove forests with lagoons that remain closed by sand bars during several winter-spring months. This generates hyper salinity and anoxic conditions during the snappers' nursery time, potentially leading to suboptimal growth conditions. In large coastal lagoons with extensive mangrove forests located in mainland coastal areas (Contreras-Espinosa and Warner 2004), oceanographic dynamics enhance suitable habitats for a great diversity of species, including snappers' prey (González-Acosta et al. 2004). Once L. argentiventris leaves the mangrove forests, growth rates decrease exponentially. Between years one and five they grow an average of $5 \mathrm{~cm}$ per year; then they grow only an average of $1 \mathrm{~cm}$ per year (Cruz-Romero et al. 1996; Martinez-Andrade 2003; Rojas et al. 2004).

\section{Mangrove nursery stage}

Once in the mangrove roots, Lutjanus argentiventris juveniles are restricted to a few $100 \mathrm{~m}$ of suitable nursery habitat, follow the movement of tides and display hunting activities as seen in other snapper species (Sheaves 2001; Dorenbosch et al. 2004a). None of the individuals collected inside mangroves during this study was sexually mature and, like other snapper species (Sheaves 1996), all L. argentiventris collected were young-of-the-year. Additionally, of 11,588 L. argentiventris individuals recorded in 1,014 underwater visual transects inside mangrove roots, only 2 were individuals $>25 \mathrm{~cm}$.

If the recruitment season begins in mid summer (August), new juveniles start using mangrove roots toward 
the end of fall and early winter. Approximately eight months later, at the beginning of the following summer, juveniles migrate from mangrove forests to adjacent habitats (rocky shores), indicating that mangrove roots provide an intermediate nursery habitat (Mumby et al. 2004) where juvenile snapper gain protection and increased survivorship during the variable conditions typical of the cold season in the Gulf of California (Aburto-Oropeza and Balart 2001).

Finally, we have monitored small bays with mangroves (particularly Balandra) at the appropriate temporal resolution to observe that when the density of juveniles inside the mangrove roots decreases, the density of individuals between 10 and $20 \mathrm{~cm}$ increases in rocky shores outside the coves (Aburto-Oropeza 2009). Less than $1 \%$ of L. argentiventris surveyed during the monitoring program in Balandra were in sandy habitats. Migratory individuals leave mangrove habitats following the rocky shoreline to the rocky points in the mangrove adjacent habitats. General observations in several rocky points indicate that they form shoals and congregate in these habitats for a few months. Once they migrate to shallow rocky reefs, the abundance of these migratory individuals decreases rapidly in the adjacent mangrove habitats and can reach zero in a few days, just before the winter season starts (Aburto-Oropeza 2009).

Ontogenetic habitat shifts and its implications

When they are still Young Lutjanus argentiventris $(<3$ years-old, 20-30 cm TL), occur in shallow rocky reefs with patches of hard corals (mainly Poecillopora spp.). As they grow, they live on deep rocky reefs $(20 \mathrm{~m})$ and, in some cases, in seamounts $(30 \mathrm{~m})$, reaching maturity after the $3 \mathrm{rd}$ year of life (Martinez-Andrade 2003). Adult individuals are not frequently seen in the deep unconsolidated bottoms (rhodolith beds and black coral gardens).

Mangroves are an important habitat in the L. argentiventris life cycle and recruitment dynamics along the Gulf of California mangrove sites are very similar. Mangrove coverage and geographic location may influence nursery productivity, thus affecting population densities in neighboring habitats (Beck et al. 2001; Mumby et al. 2004). Although we did not determine the productivity of these nursery areas (individuals per square meter), this work establishes that densities of migratory L. argentiventris in reefs within a radius of $10 \mathrm{~km}$ from a mangrove habitat are one order of magnitude higher than reefs farther away. Rare records of migratory individuals were recorded in reefs $65 \mathrm{~km}$ away from a mangrove site. These results are in accordance with studies that show that populations of mangrove-nursery species are denser within a few kilometers from mangrove forests (Nagelkerken et al. 2002; Dorenbosch et al. 2004b, 2005; Nagelkerken 2007).
In order to have a sustainable L. argentiventris fishery, it is necessary to maintain the habitats that this species requires to complete its life cycle (Secor and Rooker 2005). Since the majority of sub-adult snappers were recorded less than $10 \mathrm{~km}$ from a mangrove site, it is safe to assume that there is no dispersal of juveniles from one coast of the Gulf of California to the other. This has great implications for the few and isolated mangrove sites on the peninsula, because they likely represent all existing nurseries for $L$. argentiventris populations in this coast. Establishing the relative contribution of different habitats and areas to adult recruitment of $L$. argentiventris is an important next step toward designing longer-term monitoring and conservation programs for key nursery habitats within the Gulf of California (Gillanders et al. 2003), and will provide fishery-independent data necessary for forecasting the size of year classes several years into the future (Allman and Grimes 2002). Fishing effort on fishing grounds (rocky reefs) can be adjusted according to the distance to mangrove forests. Our results allow for the possibility to model the distribution of biomass of $L$. argentiventris depending on the distance from the mangrove forest, the distribution of different marine habitats and bathymetry, in addition to other oceanographic characteristics. Consequently, it may be possible to adjust fishing pressure in relation to distribution of particular life stages. The new information on linkages between mangrove and deeper water habitats for L. argentiventris will have important consequences for future management of both the fishery for this species and the conservation of mangroves with the Gulf of California.

Acknowledgments We are grateful to E. Sala for his advice and support. We also would like to thank L. Fichman, S. Hamilton, I. Mascareñas, A. Mendoza, G. Paredes, C. Sánchez, J. Samhouri, S. Sandin, and C. Viesca for their help on density data, otolith analysis and statistics. Special thanks to C. López, P. Hull, L. Levin, E. Sala, S. Sandin and five anonymous reviewers who improved previous versions of the manuscript. This study was funded by the Moore Family Foundation, the David and Lucille Packard Foundation, The Tinker Foundation, the Robins Family Foundation, The Walton Family Foundation, PADI aware project, and the Gulf of California Program of the World Wildlife Fund.

Open Access This article is distributed under the terms of the Creative Commons Attribution Noncommercial License which permits any noncommercial use, distribution, and reproduction in any medium, provided the original author(s) and source are credited.

\section{References}

Aburto-Oropeza O (2009) The role of nursery habitats and climate variability in reef fish fisheries in the Gulf of California. $\mathrm{PhD}$ Thesis, Scripps Institution of Oceanography, La Jolla, CA, $106 \mathrm{p}$ Aburto-Oropeza O, Balart EF (2001) Community structure of reef fish in several habitats of a rocky reef in the Gulf of California. Mar 
Ecol 22:283-305 Pubblicazioni Della Stazione Zoologica Di Napoli I

Aburto-Oropeza O, Sala E, Paredes G, Mendoza A, Ballesteros E (2007) Predictability of reef fish recruitment in a highly variable nursery habitat. Ecology 88:2220-2228

Aburto-Oropeza O, Ezcurra E, Danemann G, Valdéz-Ornelas V, Murray J, Sala E (2008) Mangroves in the Gulf of California increase fishery yields. Proc Natl Acad Sci 105:10456-10459

Allman RJ, Grimes CB (2002) Temporal and spatial dynamics of spawning, settlement, and growth of gray snapper (Lutjanus griseus) from the West Florida shelf as determined from otolith microstructures. Fish Bull 100:391-403

Attrill MJ, Power M (2002) Climatic influence on a marine fish assemblage. Nature 417:275-278

Beck MW, Heck KL, Able KW, Childers DL, Eggleston DB, Gillanders BM, Halpern B, Hays CG, Hoshino K, Minello TJ, Orth RJ, Sheridan PF, Weinstein MR (2001) The identification, conservation, and management of estuarine and marine nurseries for fish and invertebrates. Bioscience 51:633-641

Biro PA, Post JR, Parkinson EA (2003) From individuals to populations: prey fish risk-taking mediates mortality in wholesystem experiments. Ecology 84:2419-2431

Cocheret de la Moriniere E, Pollux BJA, Nagelkerken I, van der Velde G (2002) Post-settlement life cycle migration patterns and habitat preference of coral reef fish that use seagrass and mangrove habitats as nurseries. Estuar Coast Shelf Sci 55:309-321

Coleman FC, Williams SL (2002) Overexploiting marine ecosystem engineers: potential consequences for biodiversity. Trends Ecol Evol 17:40-43

Coleman FC, Koenig CC, Huntsman GR, Musick JA, Eklund AM, McGovern JC, Chapman RW, Sedberry GR, Grimes CB (2000) Long-lived reef fishes: the grouper-snapper complex. Fisheries 25:14-21

Contreras-Espinosa F, Warner BG (2004) Ecosystem characteristics and management considerations for coastal wetlands in Mexico. Hydrobiologia 511:233-245

Cruz-Romero M, Chavez EA, Espino E, Garcia A (1996) Assessment of a snapper complex (Lutjanus spp.) of the eastern tropical Pacific. In: Biology, fisheries and culture of tropical groupers and snappers. ICLARM Conference Proceedings 48, pp 324-330

Dorenbosch M, Verweij MC, Nagelkerken I, Jiddawi N, van der Velde G (2004a) Homing and daytime tidal movements of juvenile snappers (Lutjanidae) between shallow-water nursery habitats in Zanzibar, western Indian Ocean. Environ Biol Fish 70:203-209

Dorenbosch M, van Riel MC, Nagelkerken I, van der Velde G (2004b) The relationship of reef fish densities to the proximity of mangrove and seagrass nurseries. Estuar Coast Shelf Sci 60:37-48

Dorenbosch M, Grol MGG, Christianen MJA, Nagelkerken I, van der Velde G (2005) Indo-Pacific seagrass beds and mangroves contribute to fish density coral and diversity on adjacent reefs. Mar Ecol Prog Ser 302:63-76

Faunce CH, Serafy JE (2007) Nearshore habitat use by gray snapper (Lutjanus griseus) and bluestriped grunt (Haemulon sciurus): environmental gradients and ontogenetic shifts. Bull Mar Sci 80:473-495

Fodrie F, Levin L (2008) Linking juvenile habitat utilization to population dynamics of California halibut. Limnol Oceanogr 53:799-812

Gillanders BM, Able KW, Brown JA, Eggleston DB, Sheridan PF (2003) Evidence of connectivity between juvenile and adult habitats for mobile marine fauna: an important component of nurseries. Mar Ecol Prog Ser 247:281-295

González-Acosta AF, Aguero GD, Aguero JD (2004) Length-weight relationships of fish species caught in a mangrove swamp in the Gulf of California (Mexico). J Appl Ichthyol 20:154-155
Harmelin-Vivien ML, Harmelin JG, Chauvet C, Duval C, Galzin R, Lejeune P, Barnabé G, Blanc F, Chevalier R, Duclerc J, Lasserre G (1985) Evaluation visuelle des peuplements et populations de poissons: méthodes et problèmes. Terre Vie 40:467-539

Koenig CC, Coleman FC (1998) Absolute abundance and survival of juvenile gags in sea grass beds of the Northeastern Gulf of Mexico. Trans Am Fish Soc 127:44-55

MacPherson E (1998) Ontogenetic shifts in habitat use and aggregation in juvenile sparid fishes. J Exp Mar Biol Ecol 220:127-150

Martinez-Andrade F (2003) A comparison of life histories and ecological aspects among snappers. Dissertation, Lousiana State University

Morris DW (2006) Ecology-moving to the ideal free home. Nature 443:645-646

Muhlia-Melo A, Guerrero-Tortolero DA, Perez-Urbiola JC, CamposRamos R (2003) Results of spontaneous spawning of yellow snapper (Lutjanus argentiventris peters, 1869) reared in inland ponds in La Paz, Baja California Sur, Mexico. Fish Physiol Biochem 28:511-512

Mumby PJ, Edwards AJ, Arias-Gonzalez JE, Lindeman KC, Blackwell PG, Gall A, Gorczynska MI, Harborne AR, Pescod CL, Renken H, Wabnitz CCC, Llewellyn G (2004) Mangroves enhance the biomass of coral reef fish communities in the Caribbean. Nature 427:533-536

Nagelkerken I (2007) Are non-estuarine mangroves connected to coral reefs through fish migration? Bull Mar Sci 80:595-607

Nagelkerken I, Dorenbosch M, Verberk W, de la Moriniere EC, van der Velde G (2000) Importance of shallow-water biotopes of a Caribbean bay for juvenile coral reef fishes: patterns in biotope association, community structure and spatial distribution. Mar Ecol Prog Ser 202:175-192

Nagelkerken I, Roberts CM, van der Velde G, Dorenbosch M, van Riel MC, de la Morinere EC, Nienhuis PH (2002) How important are mangroves and seagrass beds for coral-reef fish? The nursery hypothesis tested on an island scale. Mar Ecol Prog Ser 244:299-305

Nelson PA (2001) Behavioral ecology of young-of-the-year kelp rockfish, Sebastes atrovirens Jordan and Gilbert (Pisces: Scorpaenidae). J Exp Mar Biol Ecol 256:33-50

Nixon SW, Jones CM (1997) Age and growth of larval and juvenile Atlantic croaker, Micropogonias undulatus, from the Middle Atlantic Bight and estuarine waters of Virginia. Fish Bull 95:773-784

Ramírez-Rodríguez M, Hernández-Herrera A (2000) Pesca artesanal en la costa oriental de Baja California Sur, México (1996-1997). In: Aburto-Oropeza O, Sánchez-Ortiz CA (eds) Recursos arrecifales del Golfo de California. Universidad Autónoma de B.C.S., México

Rojas PA, Gutiérrez CF, Puentes V, Villa AA, Rubio EA (2004) Aspectos de la biología y dinámica poblacional del pargo coliamarillo Lutjanus argentiventris en el Parque nacional Natural Gorgona, Colomia. Investigaciones Marinas de Valaparaíso 32:23-36

Rooker JR, Landry AM, Geary BW, Harper JA (2004) Assessment of a shell bank and associated substrates as nursery habitat of postsettlement red snapper. Estuar Coast Shelf Sci 59:653-661

Russ GR, Lou DC, Ferreira BP (1996) Temporal tracking of a strong cohort in the population of a coral reef fish, the coral trout, Plectropomus leopardus (Serranidae: Epinephelinae), in the central Great Barrier Reef, Australia. Can J Fish Aquat Sci 53:2745-2751

Sala E, Aburto-Oropeza O, Paredes G, Parra I, Barrera JC, Dayton PK (2002) A general model for designing networks of marine reserves. Science 298:1991-1993

Sala E, Aburto-Oropeza O, Paredes G, Thompson G (2003) Spawning aggregations and reproductive behavior of reef fishes in the Gulf of California. Bull Mar Sci 72:103-121 
Secor DH (1992) Application of otolith microchemistry analysis to investigate anadromy in Chesapeake Bay striped bass Morone saxatilis. Fish Bull US 90:798-806

Secor DH, Rooker JR (2005) Connectivity in the life histories of fishes that use estuaries. Estuar Coast Shelf Sci 64:1-3

Sheaves MJ (1996) Habitat-specific distributions of some fishes in a tropical estuary. Mar Freshw Res 47:827-830

Sheaves M (2001) Are there really few piscivorous fishes in shallow estuarine habitats? Mar Ecol Prog Ser 222:279-290

Sumpton W, Jackson S (2005) The effects of incidental trawl capture of juvenile snapper (Pagrus auratus) on yield of a subtropical line fishery in Australia: an assessment examining habitat preference and early life history characteristics. Fish Res 71:335-347

Thomson DA, Findley LT, Kerstitch AN (2000) Reef fishes of the Sea of Cortez. The University of Texas Press, Austin, p 353
Wellington GM, Victor BC (1992) Regional differences in duration of the planktonic larval stage of reef fishes in the eastern PacificOcean. Mar Biol 113:491-498

Whitmore RC, Brusca RC, León de la Luz J, González-Zamorano P, Mendoza-Salgado R, Amador-Silva ES, Holguin G, GalvánMagaña F, Hastings PA, Cartron JE, Felger RS, Seminoff JA, McIvor CC (2006) The ecological importance of mangroves in Baja California Sur: conservation implications for an endangered ecosystem. In: Cartron JE, Ceballos G, Felger RS (eds) Biodiversity, ecosystems, and conservation in Northern Mexico. Oxford University Press, New York

Wilson DT, McCormick MI (1999) Microstructure of settlementmarks in the otoliths of tropical reef fishes. Mar Biol 134:29-41

Zapata FA, Herron PA (2002) Pelagic larval duration and geographic distribution of tropical eastern Pacific snappers (Pisces: Lutjanidae). Mar Ecol Prog Ser 230:295-300 